\title{
Private vs. Business Customers in the Sharing Economy - The Implications of Trust, Perceived Risk, and Social Motives on Airbnb
}

\author{
Christoph Mittendorf \\ Goethe University Frankfurt \\ mittendorf@wiwi.uni-frankfurt.de
}

\author{
Uwe Ostermann \\ Goethe University Frankfurt \\ ostermann@wiwi.uni-frankfurt.de
}

\begin{abstract}
The sharing economy is continuously changing the hospitality industry while competing with incumbent businesses over the available market share. This study examines the peer-to-peer renting service Airbnb. In particular, we investigate how social motives, trust, and perceived risk of private and business customers, alter the accommodation provider's intention to accept a booking request. Understanding the implications of private and business customers is key - not only for platform providers, but also for researchers investigating the sharing economy. In this article, we develop a questionnaire for assessing the influence of the respective customer type on trust, perceived risk, and the provider's intention. Our pretest employs survey data $(n=53)$ and principal component analysis (PCA) to prepare a clean structural equation modeling.
\end{abstract}

\section{Introduction}

Attitudes towards consumption have shifted in recent years. Whereas $\mathrm{B} 2 \mathrm{C}$ e-commerce platforms were predominant in the last decade, we now encounter $\mathrm{C} 2 \mathrm{C}$ platforms that enable individuals to disintermediate traditional commercial channels and to share excess capacity with each other effectively. These C2C platforms function as an online marketplace for private individuals. While preventing unsustainable resource consumption, they promise to be a more social, diverse, convenient, anti-capitalistic and inexpensive alternative to common means of consumption [4,5,22]. Supported by IS, this phenomenon is often referred to as the 'Sharing Economy'. Therefore, Internet-based platforms and mobile applications are often seen as the enablers of contemporary sharing economy services [22].

As the sharing economy empowers strangers to form temporary $\mathrm{C} 2 \mathrm{C}$ relationships, existing literature emphasizes the prevalence of trust as a key requirement to initiate and pursue interactions between individuals in the online environment. The need for trust to establish online relationships has been extensively elaborated in related online industries, such as the e-commerce industry. For example, Jarvenpaa et al. (1999) found that high levels of customer trust encourage online purchase intentions and help to retain online customers, whereas perceived risk negatively influences the customers' purchase intentions. Following this logic, Hoffman et al. (1999) identified the lack of trust as one of the main reasons why individuals do not undertake online transactions. In this regard, Gefen and Straub (2004) confirmed that the existence of trust and social presence are particularly important for one-time business transactions between two parties in the online environment. Whereas most research publications focus on trust from a customer perspective, the provider perspective has often been neglected. However, for the sharing economy, we assume that trust, perceived risk, and social motives also influence the providers' intentions. We have good reasons to believe that our assumptions are especially true for the hospitality industry, such as on Airbnb, as renting an accommodation for a predefined timeframe usually implies a sharing deal between two strangers.

Furthermore, we take consumerization into account. Consumerization is described as the diffusion of consumer technology into the workplace [23]. Together with mobile devices and social media applications, it is likely that employees also use sharing economy services to make things at work easier. So far, a comparative examination of the implications of trust and perceived risk of business respectively private customers on provider intentions in the sharing economy remains an open question. This study contributes to existing research by analyzing whether accommodation providers on Airbnb are more likely to accept booking requests from business or private customers. The research questions of our study are:

RQ1: Do accommodation providers trust in (perceive risk of) business and private customers differently?

RQ2: Are accommodation providers more likely to accept booking requests from business or private customers? 
We adopt and modify the research model by Nicolaou and McKnight (2006), which investigates the effects on risk, trust, and intention to use in the e-commerce industry. In this regard, we derive their findings from the sharing economy and propose a more detailed research model that seeks to explain the difference in perception of business vs. private customers, including social motives. By doing so, we contribute to the field of IS by complementing the theory of trust and risk-based decision-making on online platforms $[15,30]$. In this regard, we demonstrate the influence of trust and risk on the providers' intentions. We further, contribute to the sharing economy research by revealing possible differences in the perception of business vs. private customers on Airbnb. Finally, by incorporating the two antecedents disposition to trust and social motives in temporary $\mathrm{C} 2 \mathrm{C}$ relationships, we also contribute to trust and social theory by evaluating both antecedents in a contemporary sharing environment.

The remainder of this paper is structured as follows. In Section 2, we review the theoretical background of the sharing economy, including literature on trust, perceived risk, and social motives. In Section 3, we propose a research model and introduce our research hypotheses. In Section 4, we demonstrate our research methodology and present our preliminary survey results. We conclude our research paper by discussing the implications of our findings, limitations, and directions for future research.

\section{Related literature}

\subsection{Sharing economy}

Contemporary sharing practices are appealing to a variety of customers, as they often realize economic, cultural, organizational, and social benefits that could not be achieved with traditional ownership practices $[4,22]$. Hereinafter, we focus on the sharing economy, a hybrid market model that brings together supply and demand of private individuals on dedicated online platforms [1,4,22].

In particular, we focus on sharing in the hospitality industry $[9,53]$. We take a closer look at Airbnb, an online platform that enables its users to share, find, and request private accommodations [53]. Subsequently, we exclude all other sharing economy platforms that focus on other industries, apply uncompensated sharing practices, or offer unequal goods and services.

\subsection{Trust}

Researchers argue that trust is one of the most complex, contradictory, and confusing concepts
[36,51]. As a result, trust has been studied incessantly from different perspectives with all of its connotations in numerous disciplinary fields, such as psychology [19,54], sociology [34,49], philosophy [26,47], and economics [8,12]. Regardless of the field, researchers state that trust is always context-dependent [18], multidimensional [37], and elusive to define [14,36]. Following this logic, there is no consensus definition of trust in the online context.

In our paper, we follow the approach of Lewis and Weigert (1985) and understand trust as a collective attribute that originates from relying on actions of another individual that take place in the future [33]. Consecutive research demonstrates that the need for trust is particularly high in socially distant relationships, such as in the online environment, due to a higher transaction complexity $[28,48]$. Moreover, research states that the need for trust is always present whenever interpersonal or commercial transactions involve risk, uncertainty, or interdependencies [26,50]. Typically, with the absence of trust in the online environment, individuals would rather refrain from a transaction than to hazard a negative experience [15]. In summary, the need for trust increases with the rising dependency on other individuals, thus growing vulnerability to their misconduct $[34,49]$. Accordingly, researchers argue that trust is essential in computermediated environments, such as in crowdsourcing [11,58], e-commerce [15,46], virtual teams [27,29], and the sharing economy [24,55]. However, there is scarce literature on the implications of trust on provider intentions in the sharing economy respectively the hospitality industry.

\subsection{Perceived risk}

Perceived risk is generally defined as the extent to which one believes uncertainty exists about whether desirable outcomes will occur [41]. We follow previous research and understand perceived risk as a provider's belief about the potential negative outcomes from online and offline interactions with customers [31,56].

Perceived risk is an important barrier for online property providers who are considering whether to offer their private accommodation. In general, with regard to the e-commerce industry, where goods are sold permanently for money, property in the sharing economy needs to be returned to its owner after a predefined period of usage and condition [2,4]. Hence, there is a greater chance of misconduct of potential customers in the sharing economy [55].

The findings in existing research, together with the peculiarities of our sharing economy setup, encouraged us to evaluate the implications of trust and perceived 
risk for temporal sharing of private accommodations on Airbnb.

\subsection{Disposition to trust}

In order to control for the effect of trusting personalities of our study subjects, we introduced the personality-type control - disposition to trust. In this regard, we analyzed the effect of disposition to trust on trust in business and private customers, respectively.

Existing literature shows that disposition to trust is a personality-type control with two components: trusting stance and faith in humanity $[30,36]$. In this context, trusting stance assesses the confidence in superior outcomes when engaging in interactions with other individuals [39], whereas personal faith in humanity assesses that other individuals are typically reliable, trustworthy, and well-meaning [39].

In general, disposition to trust represents an individual's tendency to trust others [15,30]; thus serves as a plausible antecedent of trust $[15,41]$. The antecedent is the result of lifelong personal development, education, and cultural consistency $[30,39]$. Therefore, disposition to trust is highly effective in the initiation phase of one-time interactions $[15,38]$, which are common in various sharing economy setups.

\subsection{Private vs. business customer}

Harris et al. (2012) show that more and more employees use private IT for work purposes. Besides mobile devices this also holds true for private software and services [23]. Employees feel familiar with private IT and use their private IT skills in the business environment [32]. Following this logic, temporarily formed $\mathrm{C} 2 \mathrm{C}$ relationships in the sharing economy may not exclusively be between private individuals. In fact, there is an increasing number of business travelers using Airbnb for conferences, meetings, or team offsites. In this regard, 'business travel ready' listings usually possess predefined business amenities, such as 24-hour check-in, keyless entry, $\mathrm{WiFi}$, and laptopfriendly workspaces. Besides, business customers can easily expense or charge work trips to their company.

Researchers argue that trust in (perceived risk of) private individuals, such as private sellers on eBay or Amazon, does influence the buyers intention to transact [28], whereas trust in (perceived risk of) business entities, such as business sellers on Amazon [25], does not influence the buyers intention to transact.

Hence, the difference between private and business entities can alter the individuals' intention to transact. Whereas this holds true for transaction in the e-commerce industry, there is scarce literature on comparing business and private customers in a sharing environment.

\subsection{Social motives}

Previous researcher argue that social motives are a key driver for sharing intentions $[1,6,43]$. For example, Albinsson and Perera (2012) find a sense of community to be a distinct driver of participation in sharing activities [1,40]. Belk (2010) notes that sharing goes hand in hand with trust and bonding [4,6]. In addition, Ostrom (1990) argues that community memberships or the aspiration to be part of a group is one determinant of sharing intentions respectively collaborative consumption activities [40,43]. Following this logic, Hawlitschek et al. (2016) identify social experience as a motivational factor for customers and providers to participate in the sharing economy [24]. Similarly, Bucher et al. (2016) find that social motives positively influence sharing attitudes [6]. In this regard, sharing supports individuals to initiate new connections but also to maintain existing relationships; thus to maintain part of a group or to find new company in a community.

\section{Hypothesis development and research model}

In order to close the formulated research gap, we propose a research model that allows us to analyze the implications of disposition to trust on trust in business customers and private customers. We further assess the influence of trust on perceived risk of business customers and private customers, as well as the influence of the respective trust construct on the providers' intentions to accept a business and a private customer. Finally, we assess the effect of social motives on the providers' intention to accept a specific type of customer.

In our study, we focus on Airbnb, a well-known hospitality platform, which was among the pioneers of the sharing economy. We take the perspective of an accommodation provider respectively a potential host on Airbnb. Sharing an accommodation or a room with strangers on Airbnb implies high levels of risk and trust $[5,53]$. In this paper, we follow the understanding that disposition to trust can build trust by detracting the likelihood of individuals and intermediaries engaging in undesirable future actions [15,20]. We adopted disposition to trust without any changes from previous literature. In addition, we separate trust in (perceived risk of) business customers and trust in (perceived risk of) private customers from each other. With the separation of business and private customers, we are 
able to observe perceived differences of customer types, as well as their implicit implications on providers' intentions. In this regard, we examine the acceptance of business and private customers by accommodation providers on Airbnb. Moreover, we evaluate the direct effect of social motives on the providers' intentions.

\section{Table 1. Key constructs}

\begin{tabular}{|c|c|c|}
\hline Construct & Description & Reference \\
\hline $\begin{array}{l}\text { Disposition } \\
\text { to trust }\end{array}$ & $\begin{array}{l}\text { General faith in humanity } \\
\text { and belief that other people } \\
\text { are in general well-meaning } \\
\text { and reliable. }\end{array}$ & {$[15,30,36]$} \\
\hline $\begin{array}{l}\text { Trust in } \\
\text { business } \\
\text { customers }\end{array}$ & $\begin{array}{l}\text { Confidence that business } \\
\text { customers will behave in a } \\
\text { favorable way. }\end{array}$ & \multirow{2}{*}[7,31,53]{} \\
\hline $\begin{array}{l}\text { Trust in } \\
\text { private } \\
\text { customers }\end{array}$ & $\begin{array}{l}\text { Confidence that private } \\
\text { customers will behave in a } \\
\text { favorable way. }\end{array}$ & \\
\hline $\begin{array}{l}\text { Perceived } \\
\text { risk of } \\
\text { business } \\
\text { customers }\end{array}$ & $\begin{array}{l}\text { Belief about uncertain } \\
\text { negative outcomes from } \\
\text { interactions with business } \\
\text { customers. }\end{array}$ & \multirow{2}{*}[31,41]{} \\
\hline $\begin{array}{l}\text { Perceived } \\
\text { risk of } \\
\text { private } \\
\text { customers }\end{array}$ & $\begin{array}{l}\text { Belief about uncertain } \\
\text { negative outcomes from } \\
\text { interactions with private } \\
\text { customers. }\end{array}$ & \\
\hline $\begin{array}{l}\text { Accept a } \\
\text { business } \\
\text { customer }\end{array}$ & $\begin{array}{l}\text { Intention of accepting an } \\
\text { accommodation request } \\
\text { from a business customer. }\end{array}$ & \multirow{2}{*}[10,44,50]{} \\
\hline $\begin{array}{l}\text { Accept a } \\
\text { private } \\
\text { customer }\end{array}$ & $\begin{array}{l}\text { Intention of accepting an } \\
\text { accommodation request } \\
\text { from a private customer. }\end{array}$ & \\
\hline $\begin{array}{l}\text { Social } \\
\text { motives }\end{array}$ & $\begin{array}{l}\text { The aspiration to be part of } \\
\text { a group, find like-minded } \\
\text { people, and interact with } \\
\text { other sharing users. }\end{array}$ & {$[6,24,40]$} \\
\hline
\end{tabular}

Trust in customers on the sharing economy platform is among other things determined by a general trusting disposition [17]. Whereas humans have a natural disposition to trust and ability to judge trustworthiness, existing literature argues that disposition to trust is the tendency to believe in the integrity of other people [35,36]. While the effect is dependent on the environment [38], in general, people of high disposition to trust are more inclined to frame positive initial interactions with unfamiliar counterparts [56]. In our research model the antecedent, disposition to trust, directly affects the two trust constructs - trust in business and private customers, respectively.
Hypothesis 1: The stronger the providers' disposition to trust is, the more they will trust in business customers.

Hypothesis 2: The stronger the providers' disposition to trust is, the more they will trust in private customers.

Based on previous research, we conclude that high degrees of trust decrease the perception of related risk $[31,46]$. In this regard, we follow the findings of Pavlou and Gefen (2004) who identified trust as a reduction method of perceived seller risk in online marketplaces [46]. Hence, we assume that trust in business customers decreases the perceived risk of business customers engaging in unfavorable activities. Accordingly, we assume that trust in private customers decreases the perceived risk of private customers engaging in unfavorable activities.

Hypothesis 3: Increased degrees of trust in business customers will decrease the providers' perceived risk of business customers.

Hypothesis 4: Increased degrees of trust in private customers will decrease the providers' perceived risk of private customers.

Moreover, research argues that trust can be a positive direct and indirect antecedent, acting through risk perceptions, of intention to transact $[31,46]$. Therefore, we assume that trust influences the providers' intentions to accept customers on Airbnb $[15,44]$. In practice, accommodation providers have the possibility to accept and reject accommodation requests from customers on Airbnb. Given this context, we hypothesize that the providers' intention to accept accommodation request rises with increased degrees of trust [7].

Hypothesis 5: Increased degrees of trust in business customers will increase the providers' intentions to accept business customers.

Hypothesis 6: Increased degrees of trust in private customers will increase the providers' intentions to accept private customers.

Following the related work, perceived risk, on the other hand, decreases the intention of individuals to transact $[31,46]$. Therefore, we assume that perceived risk is a negative antecedent of the providers' intentions to accept customers on Airbnb [15,44]. We hypothesize that the providers' intention to accept business respectively private customers decreases with increased degrees of perceived risk [7].

Hypothesis 7: Increased degrees of perceived risk of business customers will decrease the providers' intentions to accept business customers. 
Hypothesis 8: Increased degrees of perceived risk of private customers will decrease the providers' intentions to accept private customers.

Researchers identified social motives, as a key factor to participate in the sharing economy [6,24]. In this context, Hawlitschek et al. (2016) argue that sharing enables social experiences, whereas Bucher et al. (2016) find that social motives lead to more positive and strong sharing attitudes. Based on this reasoning, we expect that social motives have an influence on the providers' intentions to accept a respective type of customer. In particular, we expect that the implications of social motives have a greater influence on private customers compared to business customers.

Hypothesis 9: Increased degrees of social motives will increase the providers' intentions to accept business customers.

Hypothesis 10: Increased degrees of social motives will increase the providers' intentions to accept private customers.

Figure 1. Proposed research model

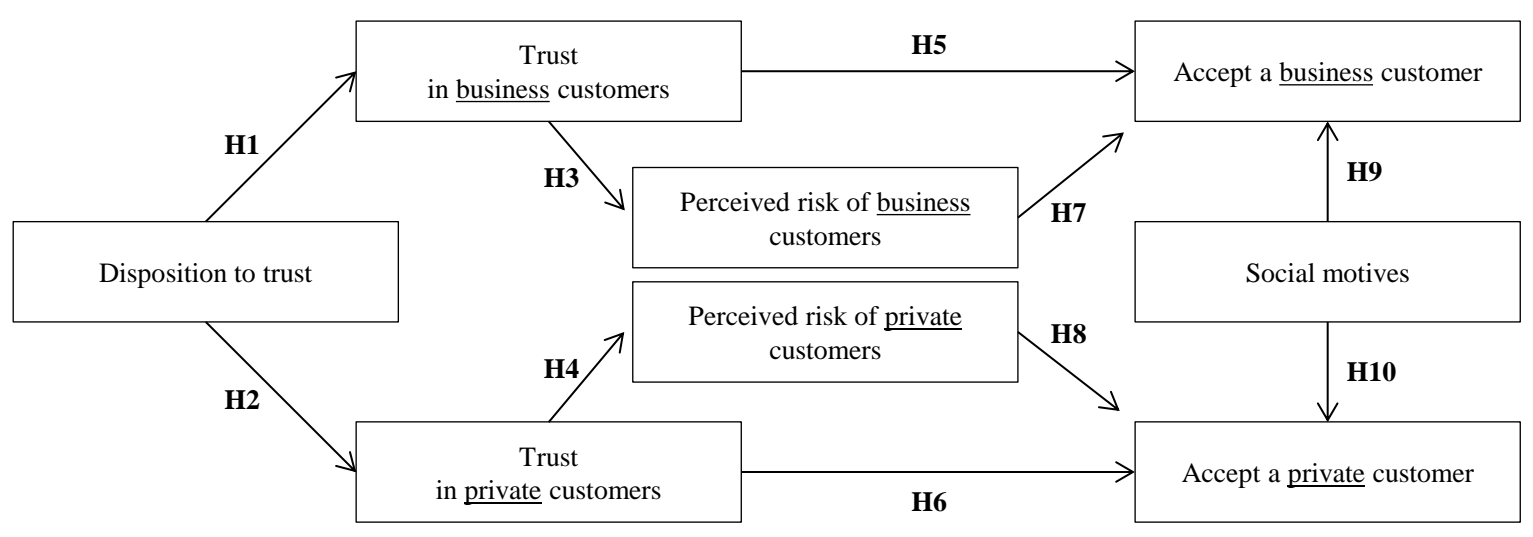

\section{Research method}

\subsection{Instrument development}

We designed the questionnaire explicitly to measure the different perception of trust in customers and perceived risk of customers, as well as their implications on the providers' intentions on Airbnb. As explained earlier, we differentiated between business and private customers. Our questionnaire contained 49 questions, covering demographic data and eight constructs. The response format was standardized using a 7-point Likert scale ranging from "strongly disagree" (1) to "strongly agree" (7). Table 3 shows an overview of the final item catalogue, including the constructs, the corresponding item codes, and the references.

We conducted the pretest survey in the spring of 2016. By the due date, 53 participants completed the questionnaire.
Table 2. Pretest Participants

\begin{tabular}{|l|l|c|c|}
\hline Attribute & Value & Freq. & Percentage \\
\hline \multirow{4}{*}{ Gender } & Female & 27 & $50.9 \%$ \\
\cline { 2 - 4 } & Male & 26 & $49.1 \%$ \\
\hline \multirow{5}{*}{ Age } & 18 to 24 years & 16 & $30.2 \%$ \\
\cline { 2 - 4 } & 25 to 34 years & 23 & $43.4 \%$ \\
\cline { 2 - 4 } & 35 to 44 years & 7 & $13.2 \%$ \\
\cline { 2 - 4 } & 55 to 64 years & 5 & $9.4 \%$ \\
\cline { 2 - 4 } & Age 65 or older & 1 & $1.9 \%$ \\
\cline { 2 - 4 } & under 18 years & 1 & $1.9 \%$ \\
\hline \multirow{5}{*}{ Profession } & $\begin{array}{l}\text { Employed for } \\
\text { wages }\end{array}$ & 21 & $39.6 \%$ \\
\cline { 2 - 4 } & Out of work & 2 & $3.8 \%$ \\
\cline { 2 - 4 } & Retired & 3 & $5.7 \%$ \\
\cline { 2 - 4 } & Self-employed & 3 & $5.7 \%$ \\
\cline { 2 - 4 } & Student & 24 & $45.3 \%$ \\
\hline
\end{tabular}

Table 3. Constructs and corresponding items

\begin{tabular}{|l|l|l|c|}
\hline Construct & Code & Item & Reference \\
\hline \multirow{3}{*}{$\begin{array}{l}\text { Disposition } \\
\text { to trust } \\
\text { (reflective) }\end{array}$} & DisTr1 & I generally trust other people. & \\
\cline { 2 - 3 } & DisTr2 & I generally have faith in humanity. & \multirow{2}{*}[15,37]{} \\
\cline { 2 - 3 } & DisTr3 & I generally trust other people unless they give me reason not to. & \\
\cline { 2 - 3 } & DisTr4 & I feel that people are generally reliable. & \\
\cline { 2 - 3 } & DisTr5 & I tend to count upon other people. & \\
\hline
\end{tabular}




\begin{tabular}{|c|c|c|c|}
\hline \multirow{5}{*}{$\begin{array}{l}\text { Trust in } \\
\text { business } \\
\text { customers } \\
\text { (reflective) }\end{array}$} & TrBC1 & I feel that business customers are honest. & \multirow{10}{*}[15,35,46]{} \\
\hline & TrBC2 & I feel that business customers are trustworthy. & \\
\hline & TrBC3 & I feel business customers are reliable. & \\
\hline & TrBC4 & I trust business customers. & \\
\hline & TrBC5 & Even if not monitored, I'd trust business customers. & \\
\hline \multirow{5}{*}{$\begin{array}{l}\text { Trust in } \\
\text { private } \\
\text { customers } \\
\text { (reflective) }\end{array}$} & TrPC1 & I feel that private customers are honest. & \\
\hline & TrPC2 & I feel private customers are reliable. & \\
\hline & TrPC3 & I feel that the private customers are trustworthy. & \\
\hline & TrPC4 & I trust private customers. & \\
\hline & TrPC5 & Even if not monitored, I'd trust private customers. & \\
\hline \multirow{5}{*}{$\begin{array}{l}\text { Perceived } \\
\text { risk of } \\
\text { business } \\
\text { customers } \\
\text { (reflective) }\end{array}$} & PRBC1 & I think it is risky to accept a business customer. & \multirow{10}{*}[46,57]{} \\
\hline & $\mathrm{PRBC2}$ & I hesitate to accept a business customer. & \\
\hline & PRBC3 & Accepting a business customer is unsafe. & \\
\hline & PRBC4 & It is likely that a business customer will fail to meet my requirements. & \\
\hline & PRBC5 & It is likely that a business customer will cause me a financial loss. & \\
\hline \multirow{5}{*}{$\begin{array}{l}\text { Perceived } \\
\text { risk of } \\
\text { private } \\
\text { customers } \\
\text { (reflective) }\end{array}$} & PRPC1 & I think it is risky to accept a private customer. & \\
\hline & PRPC2 & I hesitate to accept a private customer. & \\
\hline & PRPC3 & Accepting a private customer is unsafe. & \\
\hline & PRPC4 & It is likely that a private customer will fail to meet my requirements. & \\
\hline & PRPC5 & It is likely that a private customer will cause me a financial loss. & \\
\hline \multirow{5}{*}{$\begin{array}{l}\text { Accept a } \\
\text { business } \\
\text { customer } \\
\text { (reflective) }\end{array}$} & $\mathrm{AcBC} 1$ & I would feel comfortable accepting a business customer on Airbnb.com. & \multirow{10}{*}[10,16,44]{} \\
\hline & $\mathrm{AcBC} 2$ & I am very likely to accept a business customer on Airbnb.com. & \\
\hline & $\mathrm{AcBC} 3$ & I would accept a business customer on Airbnb.com in general. & \\
\hline & $\mathrm{AcBC} 4$ & I would not hesitate to accept a business customer on Airbnb.com. & \\
\hline & AcBC5 & If it benefits me, I would accept a business customer on Airbnb.com. & \\
\hline \multirow{5}{*}{$\begin{array}{l}\text { Accept a } \\
\text { private } \\
\text { customer } \\
\text { (reflective) }\end{array}$} & AcPC1 & I would feel comfortable accepting a private customer on Airbnb.com. & \\
\hline & AcPC2 & I am very likely to accept a private customer on Airbnb.com. & \\
\hline & AcPC3 & I would accept a private customer on Airbnb.com in general. & \\
\hline & AcPC4 & I would not hesitate to accept a private customer on Airbnb.com. & \\
\hline & AcPC5 & If it benefits me, I would accept a private customer on Airbnb.com. & \\
\hline \multirow{6}{*}{$\begin{array}{l}\text { Social } \\
\text { motives } \\
\text { (reflective) }\end{array}$} & Soci1 & Sharing is a good way to meet new people. & \multirow{6}{*}[6,24]{} \\
\hline & Soci2 & Through sharing, there is a good chance that I will meet like-minded people. & \\
\hline & Soci3 & Sharing makes me feel part of a community. & \\
\hline & Soci4 & Sharing is a good way to find company. & \\
\hline & Soci5 & Through sharing, I can make nice acquaintances. & \\
\hline & Soci6 & I value the social exchange with other sharing users. & \\
\hline
\end{tabular}

\section{Data analysis and measurement model}

To test the reliability of the measurement model we conducted a CFA and determined the factor structure of our dataset. The corresponding loadings and crossloadings (with 53 data points) of the individual items are presented in Table 6 in the Appendix.

In the next step, we assessed the validity and reliability of our survey constructs. We measured internal consistency by following the recommendations from Straub et al. (2004) and Hair et al. (2010). In order to indicate sufficient reliability, Cronbach's alpha and the Composite Reliability need to be greater than 0.70 [13].

Table 4 shows that our pretested constructs achieved Cronbach's alpha and Composite Reliability scores above this threshold.

Table 4. Descriptive statistics and reliability indices for constructs

\begin{tabular}{|l|c|c|c|c|c|c|c|c|}
\hline & DisTr & TrBC & TrPC & PRBC & PRPC & AcBC & AcPC & Soci \\
\hline Mean & 4.728 & 4.943 & 4.464 & 2.385 & 3.275 & 5.521 & 4.894 & 5.158 \\
\hline Standard Deviation & 1.315 & 1.108 & 1.193 & 1.119 & 1.437 & 1.200 & 1.434 & 1.281 \\
\hline Cronbach's Alpha ( $\alpha)$ & 0.901 & 0.895 & 0.950 & 0.942 & 0.959 & 0.940 & 0.953 & 0.933 \\
\hline Composite Reliability & 0.903 & 0.902 & 0.955 & 0.942 & 0.961 & 0.941 & 0.956 & 0.923 \\
\hline
\end{tabular}


We assessed construct validity by evaluating convergent validity [42] and discriminant validity [52]. In this context, discriminant validity is defined as the degree to which measures of two constructs are empirically distinct [3]. Researchers consider discriminant validity acceptable when the square roots of the AVE are superior to the correlations among the research constructs. Table 5 shows that there are no discriminant validity concerns. Following this logic, the variance explained by each construct is larger than the measurement error variance [45]. In addition, research argues that discriminant validity is established where the Average Shared Squared Variance (ASV) and the Maximum Shared Variance (MSV) are both inferior to the AVE for all the pretested constructs [21].

On the other hand, convergent validity is defined as the extent to which the measures for an item act as if they are measuring the underlying theoretical construct because they share variance [38]. In this regard, researchers consider convergent validity acceptable when the Average Variance Extracted (AVE) is above the threshold of 0.50 for all pretested constructs [13]. All our pretested constructs reached the recommended threshold. Based on the given statistics, we could claim convergent validity for our measurement model. In summary, our pretest results indicate strong evidence of construct validity.

Table 5. Convergent and discriminant validity coefficients

\begin{tabular}{|l|l|l|l||c|c|c|c|c|c|c|c|}
\hline & AVE & MSV & ASV & DisTr & TrBC & PRBC & PRPC & AcBC & AcPC & TrPC & Soci \\
\hline DisTr & 0.652 & 0.229 & 0.118 & $\mathbf{0 . 8 0 7}$ & & & & & & & \\
\hline TrBC & 0.651 & 0.375 & 0.101 & 0.055 & $\mathbf{0 . 8 0 7}$ & & & & & & \\
\hline PRBC & 0.766 & 0.375 & 0.117 & -0.107 & -0.612 & $\mathbf{0 . 8 7 5}$ & & & & & \\
\hline PRPC & 0.830 & 0.301 & 0.111 & -0.339 & 0.144 & 0.251 & $\mathbf{0 . 9 1 1}$ & & & & \\
\hline AcBC & 0.761 & 0.484 & 0.178 & 0.347 & 0.489 & -0.514 & -0.227 & $\mathbf{0 . 8 7 2}$ & & & \\
\hline AcPC & 0.812 & 0.484 & 0.180 & 0.382 & 0.102 & -0.322 & -0.549 & 0.696 & $\mathbf{0 . 9 0 1}$ & & \\
\hline TrPC & 0.812 & 0.254 & 0.129 & 0.479 & 0.193 & 0.023 & -0.406 & 0.292 & 0.363 & $\mathbf{0 . 9 0 1}$ & \\
\hline Soci & 0.666 & 0.254 & 0.089 & 0.448 & 0.148 & -0.012 & -0.241 & 0.050 & 0.289 & 0.504 & $\mathbf{0 . 8 1 6}$ \\
\hline
\end{tabular}

\section{Discussion and implications}

Our research attempts to understand the different perception of business and private customers in the hospitality industry. In our pretest, we took the perspective of an accommodation provider. We analyzed whether trust and perceived risk influence the providers' intentions to accept a respective type of customer on Airbnb. In addition, we tried to evaluate whether social motives influence the providers' intentions to accept a business customer and to accept a private customer differently.

Our study contributes to research in several ways. First, we show how trust, perceived risk, social motives, and customers' intentions are interconnected. Various researchers identified social interactions with potential customers as a motivational factor to offer their accommodation respectively accept booking requests on Airbnb. In particular, Bucher et al. (2016), Hawlitschek et al. (2016), and Möhlmann (2015) have shown that social motives are key drivers for participating in peer-to-peer rental services $[24,40]$. Assuming that private customers are more likely to engage in social activities with accommodation providers than business customers, the social component could compensate for missing trust and perceived risk. Thus, with our pretest, we successfully addressed an existing research gap by analyzing the different perception of business and private customers in the hospitality industry. Second, we successfully assessed the effect of trust as a positive and perceived risk as a negative direct antecedent of the providers' intention to accept customers on Airbnb. Overall, our study results indicate that trust, perceived risk, and social motives influence provider intentions and therefore affect a sharing deal in the hospitality industry. Hence, the provider perspective in the sharing economy is an important context to analyze in further research, such as for other sharing platforms.

Our pretest offers indications for practitioners of sharing economy services. Based on our expected findings, we would recommend sharing economy platforms to highlight the customer type when a service is requested. In our sharing economy setup, being a business traveler could be an additional way to signal trust to accommodation providers on the platform, hence elaborating the difference between business and private customers could be a prime concern for future research in online markets.

Our study has some limitations. First, besides the suitability of disposition to trust as an antecedent of trust in our research model, various other antecedents have been neglected in this study. Second, the sample 
size is fairly small. Whereas a sample size of 53 is generally acceptable for a pretest, a larger sample would be desirable. Third, cross-cultural effects of the given constructs have been omitted, due to the limited sample size. Fourth, we only analyzed a specific sharing economy service in one particular market. Therefore, our study is context-dependent and it is unclear whether our findings can be generalized to other sharing services, such as Couchsurfing or Uber.

\section{Conclusion}

In this paper, we focused on Airbnb, a popular example of the sharing economy. We took the perspective of an accommodation provider and investigated the implications of trust, perceived risk, and social motives on the providers' intention to accept a customer. To seek support for our research model, we conducted a pretest with 53 participants. The results of the pretest promise an adequate basis for an extended study on the subject.

\section{References}

[1] Albinsson, P.A. and Perera, B.Y. Alternative marketplaces in the 21 st century: Building community through sharing events. Journal of Consumer Behaviour 11, 4 (2012), 303-315.

[2] Andersson, M., Hjalmarsson, A., and Avital, M. Peer-topeer service sharing platforms: Driving share and share alike on a mass-scale. International Conference on Information Systems, (2013), 2964-2978.

[3] Bagozzi, R.P. and Phillips, L.W. Assessing Construct Validity in Organizational Research. Administrative Science Quarterly 36, 3 (1991), 421-458.

[4] Belk, R. You are what you can access: Sharing and collaborative consumption online. Journal of Business Research 67, 8 (2014), 1595-1600.

[5] Botsman, R. and Rogers, R. What's Mine Is Yours - How Collaborative Consumption is Changing the Way we live. Collins, 2011.

[6] Bucher, E., Fieseler, C., and Lutz, C. What's mine is yours (for a nominal fee) - Exploring the spectrum of utilitarian to altruistic motives for Internet-mediated sharing. Computers in Human Behavior 62, (2016), 316-326.

[7] Chen, J., Zhang, C., and Xu, Y. The Role of Mutual Trust in Building Members' Loyalty to a C2C Platform Provider. International Journal of Electronic Commerce 14, 1 (2009), 147-171.

[8] Chiles, T.H. and Mcmackin, J.F. Integrating Variable Risk Preferences, Trust, and Transaction Cost Economics. The Academy of Management Review 21, 1 (1996), 73-99.
[9] Cohen, B. and Kietzmann, J. Ride On! Mobility Business Models for the Sharing Economy. Organization \& Environment 27, 3 (2014), 279-296.

[10] Davis, F., Bagozzi, R., and Warshaw, P. User acceptance of computer technology: a comparison of two theoretical models. Management science 35, 8 (1989), 9821003 .

[11] Doan, A., Ramakrishnan, R., and Halevy, A.Y. Crowdsourcing systems on the World-Wide Web. Communications of the ACM 54, 4 (2011), 86.

[12] Fehr, E. On the Economics and Biology of Trust. Journal of the European Economic Association 7, 2-3 (2009), 235-266.

[13] Fornell, C. and Larcker, D.F. Evaluating Structural Equation Models with Unobservable Variables and Measurement Error. Journal of Marketing Research 18, 1 (1981), 39-50.

[14] Gambetta, D. Can We Trust Trust? 2000.

[15] Gefen, D. E-commerce: the role of familiarity and trust. Omega 28, 6 (2000), 725-737.

[16] Gefen, D., Karahanna, E., and Straub, D.W. Trust and TAM in Online Shopping: An integrated Model. MIS Quarterly 27, 1 (2003), 51-90.

[17] Gefen, D., Rigdon, E.E., and Straub, D.W. An Update and Extension to SEM Guidelines for Administrative and Social Science Research. MIS Quarterly 35, 2 (2011), iii-xiv.

[18] Gefen, D. and Straub, D.W. Consumer trust in B2C eCommerce and the importance of social presence:

Experiments in e-Products and e-Services. Omega 32, 6 (2004), 407-424.

[19] Geyskens, I., Steenkamp, J.-B.E.M., Scheer, L.K., and Kumar, N. The effects of trust and interdependence on relationship commitment. International Journal of Research in Marketing 13, 4 (1996), 303-317.

[20] Gulati, R. Does familiarity breed trust? the implications of repeated ties for contractual choice in alliances. Academy of Management Journal 38, 1 (1995), 85-112.

[21] Hair, J.F., Black, W.C., Babin, B.J., and Anderson, R.E. Multivariate Data Analysis. 2010.

[22] Hamari, J., Sjöklint, M., and Ukkonen, A. The Sharing Economy: Why People Participate in Collaborative Consumption. Journal of the Association for Information Science and Technology, (2015), 1-19.

[23] Harris, J., Ives, B., and Junglas, I. IT Consumerization: When Gadgets Turn Into Enterprise IT Tools. MIS Quarterly Executive 2012, September (2012), 99-112.

[24] Hawlitschek, F., Teubner, T., and Gimpel, H. Understanding the Sharing Economy -- Drivers and 
Impediments for Participation in Peer-to-Peer Rental. 2016 49th Hawaii International Conference on System Sciences (HICSS) 4801, (2016), 4782-4791.

[25] Hong, I.B. and Cho, H. The impact of consumer trust on attitudinal loyalty and purchase intentions in B2C emarketplaces: Intermediary trust vs. seller trust. International Journal of Information Management 31, 5 (2011), 469-479.

[26] Hosmer, L.T. Trust: The Connecting Link between Organizational Theory and Philosophical Ethics. The Academy of Management Review 20, 2 (1995), 379-403.

[27] Jarvenpaa, S.L. and Leidner, D.E. Communication and Trust in Global Virtual Teams. Organization Science 10, 6 (1999), 791-815.

[28] Jarvenpaa, S.L., Tractinsky, N., and Saarinen, L. Consumer trust in an internet store: a cross culture validation. Journal of Computer Mediated Communication 5, (1999), 135 .

[29] Kanawattanachai, P. and Yoo, Y. Dynamic nature of trust in virtual teams. The Journal of Strategic Information Systems 11, 3-4 (2002), 187-213.

[30] Kim, D.J., Ferrin, D.L., and Rao, H.R. A trust-based consumer decision-making model in electronic commerce: The role of trust, perceived risk, and their antecedents. Decision Support Systems 44, 2 (2008), 544-564.

[31] Kim, D.J., Ferrin, D.L., and Rao, H.R. A trust-based consumer decision-making model in electronic commerce: The role of trust, perceived risk, and their antecedents. Decision Support Systems 44, 2 (2008), 544-564.

[32] Köffer, S., Ortbach, K.C., and Niehaves, B. Exploring the Relationship between IT Consumerization and Job Performance. Communications of the Association for Information Systems 35, (2014), 261-284.

[33] Lewis, D.J. and Weigert, A. Trust as a Social Reality. Social Forces 63, 4 (1985), 967-985.

[34] Luhmann, N. Trust and Power. John Wiley \& Sons, 1979.

[35] Mayer, R.C., Davis, J.H., and Schoorman, F.D. An Integrative Model of Organizational Trust. Academy of Management Review 20, 3 (1995), 709-734.

[36] McKnight, D.H. and Chervany, N.L. What Trust Means in E-Commerce Customer Relationships: An Interdisciplinary Conceptual Typology. International Journal of Electronic Commerce 6, 2 (2001), 35-59.

[37] McKnight, D.H., Choudhury, V., and Kacmar, C. The impact of initial consumer trust on intentions to transact with a web site: A trust building model. Journal of Strategic Information Systems 11, 3-4 (2002), 297-323.

[38] McKnight, D.H., Choudhury, V., and Kacmar, C. Developing and validating trust measures for e-commerce:
An integrative typology. Information Systems Research 13, 3 (2002), 334-359.

[39] McKnight, D.H., Cummings, L.L., and Chervany, N.L. Initial Trust formation in new organizational relationships. Academy of Management Review 23, 3 (1998), 473-490.

[40] Möhlmann, M. Collaborative consumption: determinants of satisfaction and the likelihood of using a sharing economy option again. Journal of Consumer Behaviour 14, 3 (2015), 193-207.

[41] Nicolaou, A.I. and McKnight, D.H. Perceived information quality in data exchanges: Effects on risk, trust, and intention to use. Information Systems Research 17, 4 (2006), 332-351.

[42] O'Leary-Kelly, S.W. and Vokurka, R.J. The empirical assessment of construct validity. Journal of Operations Management 16, 4 (1998), 387-405.

[43] Ostrom, E. Collective action and the evolution of social norms. The Journal of Economic Perspectives 14, 3 (2000), $137-158$

[44] Pavlou, P.A. Integrating Trust in Electronic Commerce with the Technology Acceptance Model: Model Development and Validation. AMCIS 2001, (2001), 816-822.

[45] Pavlou, P.A. and Dimoka, A. The nature and role of feedback text comments in online marketplaces: Implications for trust building, price premiums and seller differentiation. Information Systems Research 17, 4 (2006), 392-414.

[46] Pavlou, P.A. and Gefen, D. Building Effective Online Marketplaces with Institution-Based Trust. Information Systems Research 15, 1 (2004), 37-59.

[47] Porter, T. Trust in numbers. The pursuit of objectivity in science and public life. 1996.

[48] Ratnasingham, P. The importance of trust in electronic commerce. Internet Research 8, 4 (1998), 313-321.

[49] Rousseau, D.M., Sitkin, S.B., Burt, R.S., and Camerer, C. Not so different after all: A cross-discipline view of trust. Academy of Management Review 23, 3 (1998), 393-404.

[50] Schoorman, F.D., Mayer, R.C., and Davis, J.H. An integrative model of organizational trust: Past, present, and future. Academy of Management Review 32, 2 (2007), 344354.

[51] Shapiro, S.P. The Social Control of Impersonal Trust. American Journal of Sociology 93, 3 (1987), 623-658.

[52] Straub, D., Boudreau, M.-C., and Gefen, D. Validation Guidelines for Is Positivist Research. Communications of the Association for Information Systems 13, (2004), 380-427.

[53] Tussyadiah, I.P. An Exploratory Study on Drivers and Deterrents of Collaborative Consumption in Travel. In Information \& Communication Technologies in Tourism 
2015. 2015, 817-830.

[54] Warren, M.E. Democracy and Trust. Cambridge University Press, (1999).

[55] Weber, T.A. Intermediation in a Sharing Economy: Insurance, Moral Hazard, and Rent Extraction. Journal of Management Information Systems 31, 3 (2014), 35-71.

[56] Wu, G., Hu, X., and Wu, Y. Effects of Perceived Interactivity, Perceived Web Assurance and Disposition to
Trust on Initial Online Trust. Journal of Computer-Mediated Communication 16, 1 (2010), 1-26.

[57] Zaleskiewicz, T. Beyond risk seeking and risk aversion: personality and the dual nature of economic risk taking.

European Journal of Personality 15, S1 (2001), S105-S122.

[58] Zheng, H., Li, D., and Hou, W. Task Design,

Motivation, and Participation in Crowdsourcing Contests.

International Journal of Electronic Commerce 15, 4 (2011), $57-88$.

\section{Appendix}

Table 6. Results of the principal component analysis (PCA)

\begin{tabular}{|c|c|c|c|c|c|c|c|c|}
\hline & DisTr & AcPC & AcBC & PRPC & PRBC & TrPC & TrBC & Soci \\
\hline DisTr1 & 0.873 & 0.334 & 0.303 & -0.296 & -0.093 & 0.418 & 0.048 & 0.392 \\
\hline DisTr2 & 0.749 & 0.286 & 0.260 & -0.254 & -0.080 & 0.359 & 0.041 & 0.336 \\
\hline DisTr3 & 0.747 & 0.285 & 0.259 & -0.253 & -0.080 & 0.358 & 0.041 & 0.335 \\
\hline DisTr4 & 0.856 & 0.327 & 0.297 & -0.290 & -0.091 & 0.410 & 0.047 & 0.384 \\
\hline DisTr5 & 0.803 & 0.307 & 0.279 & -0.272 & -0.086 & 0.385 & 0.044 & 0.360 \\
\hline AcPC1 & 0.357 & 0.936 & 0.651 & -0.513 & -0.301 & 0.340 & 0.095 & 0.270 \\
\hline AcPC2 & 0.368 & 0.963 & 0.670 & -0.528 & -0.310 & 0.350 & 0.098 & 0.278 \\
\hline AcPC3 & 0.347 & 0.908 & 0.632 & -0.498 & -0.292 & 0.330 & 0.093 & 0.262 \\
\hline AcPC4 & 0.322 & 0.842 & 0.587 & -0.462 & -0.271 & 0.306 & 0.086 & 0.243 \\
\hline AcPC5 & 0.325 & 0.850 & 0.592 & -0.466 & -0.274 & 0.309 & 0.087 & 0.245 \\
\hline AcBC1 & 0.306 & 0.614 & 0.882 & -0.200 & -0.453 & 0.258 & 0.432 & 0.044 \\
\hline AcBC2 & 0.317 & 0.636 & 0.914 & -0.207 & -0.469 & 0.267 & 0.447 & 0.046 \\
\hline AcBC3 & 0.306 & 0.614 & 0.882 & -0.200 & -0.453 & 0.258 & 0.432 & 0.044 \\
\hline AcBC4 & 0.304 & 0.611 & 0.878 & -0.199 & -0.451 & 0.257 & 0.430 & 0.044 \\
\hline AcBC5 & 0.278 & 0.558 & 0.802 & -0.182 & -0.412 & 0.234 & 0.393 & 0.040 \\
\hline PRPC1 & -0.314 & -0.509 & -0.210 & 0.928 & 0.233 & -0.377 & 0.134 & -0.223 \\
\hline PRPC2 & -0.314 & -0.509 & -0.210 & 0.928 & 0.233 & -0.377 & 0.134 & -0.223 \\
\hline PRPC3 & -0.311 & -0.504 & -0.208 & 0.919 & 0.231 & -0.373 & 0.133 & -0.221 \\
\hline PRPC4 & -0.315 & -0.511 & -0.211 & 0.931 & 0.234 & -0.378 & 0.134 & -0.224 \\
\hline PRPC5 & -0.287 & -0.465 & -0.192 & 0.847 & 0.213 & -0.344 & 0.122 & -0.204 \\
\hline PRBC1 & -0.099 & -0.298 & -0.475 & 0.232 & 0.925 & 0.021 & -0.566 & -0.011 \\
\hline PRBC2 & -0.093 & -0.282 & -0.450 & 0.220 & 0.876 & 0.020 & -0.536 & -0.010 \\
\hline PRBC3 & -0.093 & -0.282 & -0.450 & 0.220 & 0.875 & 0.020 & -0.536 & -0.010 \\
\hline PRBC4 & -0.092 & -0.278 & -0.444 & 0.217 & 0.865 & 0.020 & -0.529 & -0.010 \\
\hline PRBC5 & -0.089 & -0.268 & -0.428 & 0.209 & 0.832 & 0.019 & -0.509 & -0.010 \\
\hline TrPC1 & 0.427 & 0.324 & 0.260 & -0.362 & 0.020 & 0.891 & 0.172 & 0.449 \\
\hline TrPC2 & 0.444 & 0.337 & 0.271 & -0.377 & 0.021 & 0.928 & 0.179 & 0.468 \\
\hline TrPC3 & 0.448 & 0.340 & 0.274 & -0.380 & 0.021 & 0.937 & 0.181 & 0.472 \\
\hline TrPC4 & 0.461 & 0.350 & 0.282 & -0.391 & 0.022 & 0.964 & 0.186 & 0.486 \\
\hline TrPC5 & 0.369 & 0.280 & 0.226 & -0.313 & 0.017 & 0.772 & 0.149 & 0.389 \\
\hline TrBC1 & 0.044 & 0.083 & 0.399 & 0.117 & -0.499 & 0.157 & 0.815 & 0.121 \\
\hline TrBC2 & 0.048 & 0.089 & 0.427 & 0.126 & -0.535 & 0.168 & 0.873 & 0.129 \\
\hline TrBC3 & 0.045 & 0.084 & 0.402 & 0.119 & -0.503 & 0.159 & 0.822 & 0.122 \\
\hline TrBC4 & 0.047 & 0.088 & 0.422 & 0.124 & -0.528 & 0.166 & 0.862 & 0.128 \\
\hline TrBC5 & 0.035 & 0.065 & 0.313 & 0.092 & -0.392 & 0.123 & 0.640 & 0.095 \\
\hline Soci1 & 0.353 & 0.227 & 0.039 & -0.189 & -0.009 & 0.396 & 0.116 & 0.786 \\
\hline Soci2 & 0.369 & 0.238 & 0.041 & -0.198 & -0.010 & 0.415 & 0.122 & 0.822 \\
\hline Soci3 & 0.328 & 0.211 & 0.037 & -0.176 & -0.009 & 0.369 & 0.108 & 0.732 \\
\hline Soci4 & 0.393 & 0.253 & 0.044 & -0.211 & -0.010 & 0.442 & 0.130 & 0.877 \\
\hline Soci5 & 0.366 & 0.236 & 0.041 & -0.197 & -0.010 & 0.412 & 0.121 & 0.817 \\
\hline Soci6 & 0.384 & 0.247 & 0.043 & -0.206 & -0.010 & 0.431 & 0.127 & 0.855 \\
\hline
\end{tabular}

